\title{
ROLE OF TEACHER FOR PEACE EDUCATION
}

\author{
Mr. Rajendrakumar Muljibhai Parmar*
}

\begin{abstract}
This paper outlines a framework for developing peace education agenda in high schools and college and university level. Historical peace education programs are reviewed and included into a comprehensive program of substantive, peace education content and pedagogy. The historical programs reviewed include the Integral Model of Peace Education, Learning to stop War, and Master of Arts Program in Peace Education at our school, college \& University level for Peace education.

Peace is simply having a feeling of security, calm and restfulness. We often tend to think of peace as being an international issue, far from our daily life, but we do not realize that global peace can only be achieved if each country is established at peace. The peace and happiness of each country can only be achieved if every citizen is at peace. This follows therefore that a country can be peaceful and progress if people live tolerantly. We all want peace of mind. The need of the hour is to develop the young generation with peace consciousness and the importance of conflict resolution. Neither our society nor our educational system has any scope for highlighting the importance of peace and conflict resolution.

In every walk of life our attention is focused on violence, confrontation, competition, self-interest and the need to win. The history of wars is no longer than peace. It took the impact of two world wars and the Hiroshima bomb disaster for human kind to begin to perceive the concept of peace as the primary goal. Our School, college and university teacher can spread massage about the peace in the society through our studying generation. The whole reliant of peace of our nation on the student, simply they can learn and establish in society peace. Here teacher's role is very important to teach student what peace education is and how to maintain in society peace so that, every citizen can be avoid any kind of conflict from neighbor to neighbor country.
\end{abstract}

\section{Introduction}

\section{Definition}

"Peace education is a participatory holistic process that includes teaching for and about democracy and human right, nonviolence, social and economic justice, gender equality, environment sustainability, makes safe tradition, peace practices and human security"

*Assistant Professor, Shree J M Patel Institute of Social Work and Applied Arts, APMS Campus In Front of Near New Bus Stand, Anand, Gujarat, India

(C) www.ijip.in 


\section{What is peace education?}

Peace education curricula generally include instruction in conflict resolution, cooperation and interdependence; global awareness; and social and ecological responsibility. Peace education in the United States has evolved since its early nineteenth century beginnings. In the early years, peace education was promoted by a small group of New England educators, writers, and thinkers who shared a vision of the world without war or violence. Horace Mann, founder of the American common schools, considered violence in American society a mistake that required purposeful improvement and asserted that education should be the primary agent of change. In the early twentieth century, with America rapid in the forces surrounding the first and second World Wars, peace education was run down as being revolutionary. Peace educators who dreamed of a combined, peaceful world were considered un-American. In fact, these dark years for peace education continued through the following decades, fueled by the excesses of McCarthyism. This stigma greatly hampered the efforts of peace educators who overcame this setback by shifting their focus from negative peace, expressed as anti-militarism, to positive peace, with an emphasis on society-building through diminishing violence within and between nation-states. Still, whatever the generational focus, peace education has consistently reflected the desire to improve the condition of human society.

Peace means being one with life itself, Having no fear or bitterness. Peace is more than merely sitting still or in silence. Peace therefore, is a state of mind. Tagore rightly said "Where the mind is without fear and the head is held high, into that kingdom of freedom my father let my country awake". Peace is simply having a feeling of security, calm and restfulness. We often tend to think of peace as being an international issue, far from our daily life, but we do not realize that global peace can only be achieved if each country is settled and at peace.

The peace and happiness of each country can only be achieved if every citizen is at peace. This follows therefore that a country can be peaceful and progress if her people live tolerantly. We all want peace of mind. Is peace of mind possible at all in our quick life? It is up to us. We must come to grips with ourselves. Though the world may be full of problems and distress we mustSee the positive side of it all. We must accept the problem as an opportunity and not as a problem. Just as you destroy an enemy and make him your friend you can destroy a problem and turn it into joy. When there is no peace among the persons, then peace in society is in danger. Sometimes this leads to chain of violence. Lack of peace destroys the identity of a country; our mental and creative energies are diverted from useful activities to destructive one.

The need of the hour is to develop the young generation with peace consciousness and the importance of conflict resolution. Permanent damage has been done to the present generation by our system of government the political system and the religious leaders who develop emotions for their immediate means. It may not be possible to change the attitude of the present generation but it is possible to mould the future generation for the good of the nation and for mankind. We all talk about the fissiparous tendencies that come up in our country in the name of religion, place and community, which in fact are manmade barriers used in the name of God. We the educationists should think ways and means to inculcate the spirit of unity and integrity. 
$\boldsymbol{U N I C E F}$ and $\boldsymbol{U N E S C O}$ are particularly active advocates of education for peace. UNICEF describes peace education as schooling and other educational initiatives that:

- Function as 'zones of peace', where children are safe from violent conflict.

- Uphold children's basic rights as outlined in the CRC.

- Develop a climate that models peaceful and respectful behaviour among all members of the learning community.

- Demonstrate the principles of equality and non-discrimination in administrative policies and practice.

- Draw on the knowledge of peace-building that exists in the community, including means of dealing with conflict that are effective, non-violent, and rooted in the local culture.

- Handle conflicts in ways that respect the rights and dignity of all involved.

- Integrate an understanding of peace, human rights, social justice and global issues throughout the curriculum whenever possible

- Provide a forum for the explicit discussion of values of peace and social justice.

- Use teaching and learning methods that stress participation, Cupertino, problem-solving and respect for differences.

- Enable children to put peace-making into practice in the educational setting as well as in the wider community

- Generate opportunities for continuous reflection and professional development of all educators in relation to issues of peace, justice and rights.

"A culture of peace will be achieved when citizens of the world understand global problems, have the skills to resolve conflicts and struggle for justice non-violently, live by international standards of human rights and equity, appreciate cultural diversity, and respect the Earth and each other. Such learning can only be achieved with systematic education for peace."Hague Appeal for Peace Global Campaign for Peace Education

\section{The need for peace education}

If war begins in the minds of men it is because of conflict. Conflicts are of different natures: personal conflict, interpersonal conflict, communal conflict etc. The concept, Peace Education goes hand in hand with Conflict Resolution. This can be considered the primary approach for peace education. We must train our children for peace. We must create positive attitude towards peace in our young minds.

Eisner questions the extent to which our school might be responding creatively and with responsibility to the needs of one's age. He says it is important to see past issues and to go beyond immediate controversies to locate the values underlying them.

1. Do we prohibit the use of violence by teachers in the maintenance of discipline?

2. To what extent does the existing curriculum promote peace?

3. Do we encourage co-operation with competition?

4. Do we organize group projects and teamwork?

Education should be infused with aims and purposes set forth in the charter of the United Nation, the constitution of $\boldsymbol{U N E S C O}$ and the universal declaration Human Rights. Articles 26 states.... 
"Education shall be directed to the full development of the human personality and to the strengthening of respect for human rights and fundamental freedom, It shall promote understanding, tolerance and friendship among all nations, racial or religious groups and shall further the activities of the United Nations for the maintenance of peace".

World famous thinker Frit of Capra notes that "At the beginning of the last decades of our century we find ourselves in a profound worldwide crisis. It is a crisis of intellectual, moral and spiritual dimensions, a crisis of scale and urgency unprecedented in recorded human history". He goes further to suggest "We have to shift our perspective from the end of the twentieth century to a time span surrounding thousands of years." The Industrial revolution took a wrong turn promoting consumerism and militarism. The militarism encouraged the promotion of mask industry, which indirectly influenced the war. Peace education on the lines of thought and the action, which tries to break such values.

\section{How do we expect peace in our children?}

We have to change our outlook towards society. For the sake of quarrel, people may say that the moral education and religious education adequately covers the principles of peace education but infect it gives glorification of only one religion or the other. We want our children to go beyond the four walls of religion and spread the human values to build a peaceful world.

\section{Peace education to be introduced in schools}

With stress levels among people on the rise and tempers flaring up easily, it is time for 'peace education' in schools and the NCERT is all set to train teachers in conflict resolution techniques and ways to undermine violence, aggression. Aiming to arm teachers with skills to promote a sense of harmony with oneself and social environment among students for avoiding conflict with law,she said the teachers are the role models for students and hence they can help their pupils handle the day-to-day situations in a non-violent way. Arrogance and aggression, which propel violence, are two vices that can be controlled by value-based education; she said adding the students come across trying situations at their home, educational institutions and other places and tend to commit crime.

The course assumes significance in view of increasing rate of crime committed by children in the country, she said. According to the National Crime Record Bureau (NRCB), as many as 8561 cognizable crimes under IPC were committed by juveniles in 1994, which increased to 16,509 in 2001. It further soared to 18,560 in 2002 and remained at 17,819 in 2003.

As many as 288 murder cases committed by juveniles were reported in 1994, which went up to 531 and was recorded at 465 in 2002 and 2003, respectively. Similarly, 176 cases of rape committed by juveniles were reported in 1994. In 2003, the figure touched 466, according to the NCRB data. In 2004, about 3234 juveniles were apprehended for different crimes, including 583 cases, where arrests were made on charges of murder. 


\section{The Current State of Teaching for Peace in Higher Education}

Educators at all levels generally agree that students should be taught about peace. This is especially true in the current political climate in the United States. Fewer seem to consider teaching for peace in the same light. Yet peace education entails more than just content. It also includes how we craft our learning environments and the teaching methods we use. Peace educators are quick to admit that structure and processes are critical elements of a peace-making pedagogy.

Eisner (2000) explains that students are "educated" by three different elements; the content, or the material that is included; the processes or the methods used to transmit information; and through the ways that schooling is structured. In addition, two models or frameworks generally guide education in the United States. These are "systems of belief that either nurture and support-or inhibit and undermine-equitable, democratic, nonviolent and caring relations". The dominator model, described as dominator pedagogy or war-making pedagogy in this paper, reflects the militaristic culture in which we live. It is characterized by authoritarianism and male dominance. It stresses the importance of competition and ranking. The dominator model includes a supporting ideology making these structural arrangements appear to be right and even common sense. Education in the United States is often structured in ways that are dualistic, antagonistic and confrontational, all militaristic values.

\section{Achieving peace}

Peace is not sold in the market. Peace is personal as well as universal. Today, society is awakening to the reality of give somebody the use of a hand.This is a good sign of peace. A caring people are a sign of hope. All of us have to put our shoulders to the wheel if we want a better tomorrow.

\section{Peace through co-operation}

There is only one way to get peace through cooperation. Non co-operation will only create tension, anger, dislike and revolution. Whether in a family, a class, staff, a team, a country; it is necessary to have a homely atmosphere, an atmosphere that is favorable to thinking about the meeting of minds and heads. If there is no co-operation then each one will seek faults in others and no progress will take place.

Compare the rule of Akbar with Aurangzeb. Power does not bring peace. It is how we use this instrument of power that matters. Power used as authoritarianism may only bring terror and disaster. An authoritarian minister is as bad as an autocratic ruler to his son or daughter, such priest will create disobedient children and peace in the home will be crushed.

\section{Peace through love}

It is not true that careful the stick spoils children. The rod has to be used only when other measures fail. But love never fails. Love should not be possessive, selfish or demanding. Love 
should be spontaneous, unconditionally showered all the time. Love generates faith, true cooperation and this is what is essential for peace.

"When we love we share and not tear, when we love we win and not lose, when we love, we open and not close, when we love we progress and not move away, when we love, we co-operate and not break up."

\section{Principal themes in education for peace}

Educating for peace is concerned to help students develop a rich vision of peace which should form part of his personal life. He should understand the fullness of his own religion and appreciate all other religions. Educating for peace is also concerned with developing values and skills to assist the students in striving for the fullness of life that embraces all people. Educating for peace is concerned with helping the students to recognize the many forms and causes of violence and to promote values and skills for living in society.

Educating for peace is helping students to the awareness of peace and to find ways of keeping peace by conflict resolution.Educating for peace is helping students to be aware of interdependence, compassion and sensitivity for the needs of others and to encourage them to help in building a nation and not in destroying it. Education for peace is helping students to enjoy the environment, to value the relationship of man and environment, to work individually and collectively for the betterment of the world. Educating for peace is providing students the vision towards a peaceful, loving and just world. Use children to save the world.

Peace Education should be a part of the school syllabus. Peace is a value. Values involve interaction between intellectual and emotional development of a child. In the subconscious of every child is impulse. Attitude and values give direction and quality to an action. The students accept the stimulus in the form of planned activities. He responds and reacts to them, which brings pleasure or displeasure. He learns to value the feelings of peace and harmony and responds accordingly.He develops thoughts, ideas and images consistent with the value of peace as priority in his personal life.

\section{KEY SKILLS, METHODS AND CONTENT}

- Peace Education skills

- Identifying bias

- Problem solving

- Sharing and co-operation

- Shared decision-making

- Analysis and critical thinking

- Enhancing the self-esteem of oneself and others

- Creative self-expression

- Ability to imagine life beyond the present and work towards a vision

- Understanding the links between the personal, local and global

- Honest talk and sensitive listening

- Positive emotional expression 
- Recognizing and expressing feelings in ways that are not aggressive or destructive

- Conflict resolution strategies

- Empathy

- Nonviolent action in relation to problems both personal and societal

- Ability to act on ideas

- Self-reflection

- Independent research

\section{Teacher's Role in Peace Education}

In the early 1970s a group of the world's leading scientists; the Club of Rome brought together their expertise in a study of the whole world's present problems. When they brought together the insights gained from their separate disciplines they became aware that all the major world problems that we think of under separate headings are, in reality, so closely related as to be aspects of one problem. They called this group of worldwide interconnected problems. "The human problem" and stated that real solutions apparently are interdependent. Finally, the scientists stated that these problems are not technological but are ethical problems.

First, the teacher must understand that multicultural, multiethnic, and multireligious problems in society are not to be dealt with in isolation in bits and pieces of a good peace education program but, being interconnected with all other problems of peace and violence, are addressed in the whole program. For example, developing such qualities as compassion and service to others can help reduce racial, religious, or other prejudices, but students of all backgrounds must take part in the program.

Second, the teacher must be cognizant and wholly supportive of the basic nature and aims of peace education, one example given before from Dale Hudson being: "...education that actualizes [people's] potentialities in helping them learns how to make peace with themselves and with others, to live in harmony and unity with self, humankind and nature." The principles upon which this statement rests include:

1. The basic requirement for world peace is the unity of humankind.

2. World order can be founded only on the consciousness of the oneness of humankind.

It follows that, in this view, the teacher of peace education in an apparently diverse society must keep certain basic aims in mind: the achievement of a unified, peaceful society both globally and within the nation, where world citizenship is fostered and "unity in diversity" is recognized and practiced.

Third, the teacher should constantly keep in mind that the attainment of any aim is conditioned upon knowledge, volition, and action.

The power needed to accomplish a peaceful world is the unification of humankind. To this end, the teacher must use his or volition and will-power. In the words of Sarvepalli Radhakrishnan, we should “... will peace with our whole body and soul, our feelings and instincts, our flesh and its affections.”

In our experience, when a teacher becomes deeply and regularly involved in teaching peace education, this can cause that teacher to take a long, deep look at his or her values and 
beliefs. Clearly, it can center a person on one's own thoughts, words, and deeds. In order to be a model for the students, the teacher has the opportunity of transformation and change of the inner self. Then the students can be helped to understand and feel what is a peaceful person who is a peacemaker, and the teacher will have a powerful, positive influence on hundreds and thousands of children and youth.

\section{Conclusion}

It is important to remember that peace education is not an additional academic subject we add to the offered system. Instead, it is the general orientation that we introduce in the accessible subjects, textbooks and teacher discourses. For instance, the Sociology textbooks could underscore the fact that peaceful coexistence is an objective requirement for peaceful development, and vice versa. In the Physics textbooks, emphasis could be laid on the need to fight for a ban on nuclear weapons and other weapons of mass destruction, and international agreements in this field. Biology books could explain, among other things, the deadly effects of exposure to radioactivity on human beings. Needless to say, one who wills the end wills the means. Though international comparisons are difficult, general lessons and indicative suggestions can be taken from international experiences also. Increasing recognition of the essential role of youth in peace building is now beginning to manifest itself in efforts to actualize that role. The future moral, social, and political challenge will be to see whether humanity can mobilize the energy, creativity, and vision of youth in pursuit of peace as successfully as it has in pursuit of war.

The challenge for educators all over the globe is to choose between going ahead with the present effete educational system, or preparing our younger generation for the kind of life each and every one of us aspires towards. To use Swami Vivekananda categorization, should we teach them just 'to know' or 'to be'?

\section{Reference}

1. Sanjay Prakash Sharma, Technological changes in Education, $1^{\text {st }}$ Edition 2007, Vista International Publishing House, V-196, Near Shiv Sadhan Mandir; C-11 Yamuna Vihar Delhi- 110053

2. Yogesh K Sharma, Fundamental aspect of educational, $2^{\text {nd }}$ Edition, 2005, Kanishika Publishers \& Distributers, 4697/5-21A, Ansari Road, Dariyagunj New Delhi - 110002

1. Www. APA. org.

2. Www. Buzzle.com

3. Www. Google.Com

4. WWW. Wikipedia.com 